\title{
Nutritive and Anti-Nutritive Composition of Xylopia parviflora Seed Obtained from Pati Shabakolo in Lavun Local Government Area, Niger State, Nigeria
}

\author{
Elijah Yanda Shaba ${ }^{1}$, Tsado John Mathew ${ }^{1, ~}{ }^{*}$, Amos Ndarubu Tsado ${ }^{2}$, Abdulfatai Aiyede Otori ${ }^{3}$, \\ Emaka Ogbonna ${ }^{1}$
}

${ }^{1}$ Department of Chemistry Federal University of Technology, Minna, Niger State, Nigeria

${ }^{2}$ Department of Basic and Applied Sciences, Niger State Polytechnic Zungeru, Nigeria

${ }^{3}$ Department of Chemical Engineering, Federal Polytechnic, Bida Niger State, Nigeria

Email address:

chimistzionist@yahoo.com (E. Y. Shaba),johntsadom@gmail.com (J. T. Mathew)

${ }^{*}$ Corresponding author

\section{To cite this article:}

Elijah Yanda Shaba, Tsado John Mathew, Amos Ndarubu Tsado, Abdulfatai Aiyede Otori, Emaka Ogbonna. Nutritive and Anti-Nutritive Composition of Xylopia parviflora Seed Obtained from Pati Shabakolo in Lavun Local Government Area, Niger State, Nigeria. Cell Biology. Vol. 5, No. 5, 2017, pp. 53-56. doi: 10.11648/j.cb.20170505.12

Received: July 26, 2016; Accepted: September 6, 2016; Published: August 30, 2017

\begin{abstract}
Determination of nutritive value of Xylopiaparviflora seed was carried out using standard analytical methods. The proximate parameters determined were moisture content $(8.95 \pm 1.93) \%$, ash content $(6.25 \pm 0.35) \%$, crude fibre $(8.25 \pm$ $0.57) \%$, crude protein $(8.28 \pm 0.19) \%$, fat $(6.08 \pm 0.46) \%$ and carbohydrate $(62.45 \pm 0.76) \%$ as well as calorific value $(337.60 \pm 0.32 \mathrm{KJ} / 100 \mathrm{~g})$ respectively. The result of this sample revealed that the seed of Xylopiaparviflora contains reasonable amount of mineral contents needed in diet with potassium concentration of $(53.21 \pm 0.31 \mathrm{mg} / 100 \mathrm{~g})$, phosphorus $(50.22 \pm 0.43$ $\mathrm{mg} / 100 \mathrm{~g})$, sodium $(49.50 \pm 0.42 \mathrm{mg} / 100 \mathrm{~g})$, magnesium $(22.58 \pm 0.62 \mathrm{mg} / 100 \mathrm{~g})$ and iron content $(26.41 \pm 0.28 \mathrm{mg} / 100 \mathrm{~g})$ as well as copper concentration $12.42 \pm 0.14 \mathrm{mg} / 100 \mathrm{~g}$. The highest and lowest essential and non-essential amino acid composition of this seed were glutamic acid $(13.18 \mathrm{~g} / 100 \mathrm{~g})$ and tryptophan $(0.65 \mathrm{~g} / 100 \mathrm{~g})$ and leucine $(5.79 \mathrm{~g} / 100 \mathrm{~g})$ and cystine $(0.66 \mathrm{~g} / 100 \mathrm{~g})$ respectively. The anti-nutritional factors were also determined which revealed that the result were all below toxic level and therefore may not cause any effect on man and his animal when taken.
\end{abstract}

Keywords: Xylopiaparviflora Seed, Nutritive, Mineral, Anti-nutritional and Amino Acid

\section{Introduction}

Plants are nature's gift to mankind. These wild plants are one of the main sources of vitamins, minerals and proteins. These constituents are essential for normal physiological wellbeing and help in maintaining healthy state through development of resistant against pathogens. Fruits and seeds from the wild is the major alternative to many people during shortage of food [1]. Plant seeds are a good source of food for animals as well as humans, since they contain nutrients necessary for plant's growth, including many healthy fats, such as omega fats [2]. In different part of the world, products of natural tree are very important to human diets and are also good source of income [3]. These fruit and seed are good source of vitamins, essential minerals and carbohydrates in form of cellulose, starch and soluble sugar [4]. Mainly crudely consumed, they improve the daily food ration as an energy source and through their content in micronutrients. Consumption of indigenous trees products is among strategies to supplement diets [5]. Several tree products which play pivotal role exist but undervalued and are seasonal [3]. It is now known that agricultural materials are used as animal feeds and they contain some nutritional values.

Fruits and seed are now occupying important position in our daily life as diet and feeding supplements and so 
adequate knowledge is required on wild fruits which contain these nutrients. However, most of these products have received little research attention, particularly their nutritional compositions. There are contribution to local diets is less understood and quantified. Therefore, the study was done to determine the proximate composition, minerals and amino acids content of these wild seed.

Xylopiaparviflora is a shrub or small tree of about $17 \mathrm{~m}$ high in fringing forest of the lowland rain-forest and savanna zones from Senegal to Nigeria. The wood is yellow, hard, fine-grained and elastic. Its flexibility and durability render it suitable for oars and masts. It is believed to resist termites, and is used for house-posts, scantlings and general carpentry. The bark is fibrous from which cordage can be made. In the Casamance, an aqueous decoction of equal parts of roots and leaves is taken by mouth as a bechic and expectorant [6].

\section{Methodology}

\section{Sample Collection and Preparations}

The seeds of Xylopiaparviflora used were obtained from Patishabakolo, Lavun local Government, Niger State, Nigeria. The seeds were obtained and the shells were crack to separate the seeds from the shell. The seeds were collected and spread out on flat surface which was dried in the laboratory under room temperature for two weeks for proper drying after which the samples were grind into fine powder using a mortar and pestle.

\subsection{Proximate Analysis}

The standard analytical procedures for food analysis were adopted for the determination of moisture content, crude protein, crude fibre, percentage lipids, carbohydrate, ash, and energy value as outline by AOAC [7]

\subsection{Mineral Analysis}

Sodium and potassium were determined using gallenkamp Flame analyzer, while calcium, magnesium, iron, manganese, zinc and copper were determined using buch Model 205 Atomic absorption spectrophotometer. Phosphorus level was determined using the phosphovanadomolybdate colorimetric techniques on JENWAY 6100 Spectrophotometer Pearson (1976).

\subsection{Determination of Amino Acid Profile}

Amino acid profile of the sample was carried out by utilizing the routines depicted. The sample was dried and constantly weights, defatted, hydrolyzed, vanished into a revolving evaporator and stacked into the Techanicon sequential Multi-Sample Amino Acid Analyzer (TSM).

\subsection{Anti-nutritional Factors}

The Anti-nutritional Factors were analyzed based on the methods described by Krishnaiah et al. [8].

\section{Results and Discussions}

Table 1. Results of the proximate composition of Xylopiaparviflora in \% except the calorific value in $\mathrm{KJ} / 100 \mathrm{~g}$.

\begin{tabular}{ll}
\hline Parameters & Value \\
\hline Moisture content & $8.95 \pm 1.13$ \\
Ash content & $6.25 \pm 0.35$ \\
Crude fibre & $8.25 \pm 0.57$ \\
Crude protein & $8.28 \pm 0.19$ \\
Fat (lipid) & $6.08 \pm 0.46$ \\
Carbohydrate & $62.45 \pm 0.76$ \\
Calorific value & $337.60 \pm 0.32$ \\
\hline
\end{tabular}

KEY: The values are means of duplicate determinations \pm standard deviations (SD).

Table 2. The results of Mineral contents of Xylopiaparviflora $(\mathrm{mg} / 100 \mathrm{~g})$.

\begin{tabular}{ll}
\hline Parameters & Values \\
\hline Sodium & $49.50 \pm 0.42$ \\
Potassium & $53.21 \pm 0.31$ \\
Magnesium & $22.58 \pm 0.62$ \\
Iron & $26.41 \pm 0.28$ \\
Zinc & $13.03 \pm 0.10$ \\
Manganese & $16.20 \pm 0.22$ \\
Copper & $12.42 \pm 0.14$ \\
Phosphorous & $50.22 \pm 0.43$ \\
\hline
\end{tabular}

The values are means of duplicate determinations 土standard deviations

Table 3. The results of anti-nutritional composition of Xylopiaparviflora (mg/lo0g).

\begin{tabular}{ll}
\hline Parameters & Values \\
\hline Oxalate & $0.24 \pm 0.01$ \\
Tannins & $0.91 \pm 0.02$ \\
Saponnin & $2.61 \pm 0.05$ \\
Alkaloids & $3.03 \pm 0.11$ \\
Cyanides & $2.09 \pm 0.01$ \\
Flavonoids & $1.10 \pm 0.03$ \\
\hline
\end{tabular}

The values are means of duplicate determinations 土standard deviations

Table 4. The result of the amino acid profile of Xylopiaparviflora in $\mathrm{g} / 100 \mathrm{~g}$ protein.

\begin{tabular}{ll}
\hline Parameters & Concentration \\
\hline Lysine & 5.00 \\
Histidine & 2.21 \\
Arginine & 8.72 \\
Aspartic acid & 11.10 \\
Threonine & 2.24 \\
Serine & 3.09 \\
Glutamic acid & 13.18 \\
Proline & 2.54 \\
Glycine & 3.24 \\
Alaline & 3.57 \\
Cystine & 0.66 \\
Valine & 4.29 \\
Methioline & 2.08 \\
Isoleucine & 3.23 \\
Leucine & 5.79 \\
Tyrosine & 2.22 \\
Phynylalaline & 4.22 \\
Tryptophan & 0.65 \\
\hline
\end{tabular}




\section{Discussion of Results}

The result of the proximate composition is shown in table 1 which revealed that the seed contains relatively small amount of fat content of $6.08 \pm 0.46 \%$. The value obtained in this work was high when compared with the values of $0.43 \%$ in the seed of Parkiafilicoidea reported by [9]. Crude fibre of $8.28 \pm 0.19 \%$ was obtained in this work. The value was observed to be high when compared to the seeds of Alternantherasessilis (5.32\%) reported by [10]. The value of the moisture content was $8.95 \pm 1.13 \%$ which are high when compared to $6.05 \%$ observed from Moringaoleifera as reported by [11]. The seed which contain low level of moisture content based on the safe storage limit of moisture (15\%) for seeds suggest that it can be stored for a very long period of time without spoilage [11].

The ash content was $6.25 \pm 0.35 \%$, this result is high compared to $2.00 \pm 0.00 \%$ for cherry seed reported by [2], though the value of ash content is low when compared to that of Talinumtriangulare seed (19.5\%) which is locally consumed in Nigeria as reported by [12]. The high ash content values of the samples indicates that the high quantity of inorganic minerals were present. Crude fibre was $8.25 \pm 0.57 \%$, this value was lower than orange seeds $(11.0 \%)$ and red roselle $(28.50 \%)$ reported by [13] The value of crude fibre falls within the range of value reported most seeds [14]. The value of crude protein of the seed sample was $8.28 \pm 0.19 \%$. This value is high when compared to that of Commelina mudifera $1.42 \%$ [15]. This result therefore suggests that the seed may contribute significantly to the dietary intake of man and his animals. This sample also revealed that the carbohydrate content is moderately high $62.45 \pm 0.76 \%$ which may be a good source of energy to the body. This value was high when compared to $17.56 \%$ of Corchorusolitorius seed, $7.27 \%$ of Sennasiamea and $3.75 \%$ of Commelinanudiflora reported by [16].

The result of the mineral composition of the seed of Xlopiaparviflora is shown in table 2. The sample contains $49.50 \pm 0.42 \mathrm{mg} / 100 \mathrm{~g}$ of sodium concentrations. This value was high when compared to $1.96 \mathrm{mg} / 100 \mathrm{~g}$ obtained in cocoa bean reported by [14]. The high obtained from the sample is an indication that the seed can serve as dietary supplement for sodium. Potassium content was found to be $53.21 \pm 0.31 \mathrm{mg} / 100 \mathrm{~g}$. This value was higher than the $13.93 \pm 0.10 \mathrm{mg} / 100 \mathrm{~g}$ reported for cherry seed by [2]. Adequate intake of this mineral from the diets may be found to lower blood pressure by antagonizing the biological effects of sodium [17]. Magnesium concentration of this sample was $22.58 \pm 0.62 \mathrm{mg} / 100 \mathrm{~g}$. The value was high when compared to 7.76 and $6.65 \mathrm{mg} / 100 \mathrm{~g}$ for Parkiabiglobosa and Boerhaviadiffusa by [18]. Iron content of $26.41 \pm 0.28 \mathrm{~m} 100 \mathrm{~g}$ was recorded in this work, though the value was high compared to $0.13 \mathrm{mg} / 100 \mathrm{~g}$ in $B$. diffusa, $0.016 \mathrm{mg} / 100 \mathrm{~g}$ in $C$. nudiflora reported by [11]. The zinc content of $13.03 \pm 0.10 \mathrm{mg} / 100 \mathrm{~g}$, this value was high compared to those reported in Blighiasapida $3.30 \mathrm{mg} / 100 \mathrm{~g}$ and $C$. nudiflora $4.2 \mathrm{mg} / 100 \mathrm{~g}$ [19]. Copper concentration obtained from this sample was $12.42 \pm 0.14 \mathrm{mg} / 100 \mathrm{~g}$. The value was high when compared to $2.41 \mathrm{mg} / 100 \mathrm{~g}$ for $C$. olitorius and $0.2 \mathrm{mg} / 100 \mathrm{~g}$ for L. Africana seed [18]. Phosphorus content was $50.22 \pm 0.43 \mathrm{mg} / 100 \mathrm{~g}$. The value was very low when compared to $4000 \mathrm{mg} / 100 \mathrm{~g}$ obtained for Beni seeds [20]. Therefore, the seed can serve as a good source of mineral for several biological activities.

The result of anti-nutrient of Xylopiaparviflora seed was shown in table 3. Saponin content of $2.61 \pm 0.05 \mathrm{mg} / 100 \mathrm{~g}$ was recorded in this work. Saponins are known for reducing the uptake of certain mineral element including glucose [11]. Tannin concentration analyzed in this sample was $0.91 \pm 0.02 \mathrm{mg} / 100 \mathrm{~g}$. Tannin has the ability of precipitating certain protein and thereby making them indigestible [11]. Alkaloid content of this sample was $3.03 \pm 0.11 \mathrm{mg} / 100 \mathrm{~g}$. Alkaloids are often toxic to men and may have dramatic physiological activities hence they are widely used in medicine [21]. Oxalate content was $0.24 \pm 0.01 \mathrm{mg} / 100 \mathrm{~g}$. The presence of oxalate in the food causes irritation in the mouth and interferes with absorption of divalent minerals particularly calcium by forming insoluble salts [22]. Flavonoid concentration obtained from this sample was $1.10 \pm 0.03 \mathrm{mg} / 100 \mathrm{~g}$. Flavonoids which are phenolic compounds that serve as flavoring ingredient of spices and vegetable [21]. These anti-nutritional factors can be minimized to tolerable limit by proper processing methods such as cooking, frying and soaking.

Table 4 shows the values of amino acid concentration of the analyzed seed of Xlopiaparviflora. The seed which are rich in essential amino acids such as lysine, histidine, threonine, valine, methioline, isoleucine, leucine, phynylalaline, tryptophan and the non-ssential amino acids such as arginine, serine, proline, glycine, alaline, cystine, tyrosine. Glutamic acid is recorded to have the highest value $13.18 \mathrm{~g} / 100 \mathrm{~g}$ protein and tryptophan $0.65 \mathrm{~g} / 100 \mathrm{~g}$ protein had the least amino acid concentration present in the seed. The value of the essential amino acid such as glutamic acid $(13.18 \mathrm{~g} / 100 \mathrm{~g})$ and aspartic acid (11.10g/100g) are comparable to that of [23].

\section{Conclusion}

The information provided in this study showed that the seed of Xylopiaparviflora increases our knowledge on the use of this wild seed as diet and can function as a food supplement. The seeds of Xylopiaparviflora which are characterized by high carbohydrate content and also high mineral content as observe for $\mathrm{K}, \mathrm{P}$ and $\mathrm{Mg}$ and also relatively reasonable amount of $\mathrm{Na}, \mathrm{Ca}, \mathrm{Fe}, \mathrm{Zn}, \mathrm{Cu}$ and $\mathrm{Mn}$ were found present. The seeds are also rich in some essential and non-essential amino acids such as glutamic acid, aspartic acid, arginine, leusine and lysine. Thus this wild seed could be highly nutritive and can serve as a good source of nutrient to man and his animal. 


\section{References}

[1] Thiombiano NDE, Lamien N, Castro-Euler AM, Barbara V, Agundez D, Boussim IJ. Local communities demand for food tree species and the potentialities of theirlandscapes in two ecological zones of Burkina Faso. Open J. Forest. 2012, 3: p.79-87.

[2] MathewTJ, Ndamitso MM, Otori AA, Shaba EY, Inobeme A, Adamu A.Proximate and mineral composition of seeds of some conventional and non conventional fruits in Niger state, Nigeria. Academic Research International. 2014, 5(2): p.113 118.

[3] Ayessou CN, Gueye M, Dioh E, Konteye M, Cissé M, Dornier M. Nutritive composition and energy contribution of the fruit of Maeruapseudopetalosa, a food extender inSenegal. Fruits. 2009, 64 (3): p. 1-9.

[4] Lamien N, Lingani-Coulibaly P, Traore-Gue J. Importance of local fruits consumption indiet balance in Burkina Faso, west africa. Acta Hort. 2009, 806: p. 203-208.

[5] Falconer J. "Hungry season" food from the forest. Unasylva 1990, 41: p. 14-19.

[6] Burkll HM. The useful plants of west tropical africa 1985, 1 (505): p. 457.

[7] AOAC. Official methods of analysis Association of Analytical Chemist $15^{\text {th }}$ Edition Washington DC. 2006, p. 12-135.

[8] Krishnaiah D, Devi T, Bono A, Sarbatly R. "studies on phytochemical components of six Malaysian medicinal plants", Journal of Medicine plant Research. 2009, 3 (2): p. 67-72.

[9] Oderinde RA, Ajayi IA, Taiwo VO, Agbedana EO. Dietary effects on growth, plasma lipid and tissues of rats fed with non-conventional oil of Telfairiaoccidentalis. J. Sci. Food Agric., 2004, 84: p. 1715-1720.

[10] Olaofe O. and Sanni C. O. Nutritional Component of Some non-Conventional Leaf Vegetable Consumed in CameroonFood chemistry 1988, 30: p. 73-77.

[11] Onwuka, G. I., Food analysis and instrumentation. Agric. J. Naphtali Print Lagos Nigeria 2005, p. 105-109.
[12] Adeboye GB, Ameen OM, Abass, LT. (Physicochemical properties of biodiesel produced from Jatrophacurcas oil and fossil diesel. J. Microbiol. Biotechnol. Resour. 2004, 1: p. 1216.

[13] Anwar F, Rehana N, Bhanger MI, Ashfat S, Farah NT, Felix A. Physicochemical characteristic of citrus seeds as seed oils. Pakistan Journal of American oil chemists society. 2008, 7(2): p. 112- 119.

[14] Anhwange BA, Ajibola IA, Taiwo VO, Okibe FG. Nutritive value and Anti-nutritional factors in wild seeds. Journal of Fisheries International, 2006, 2: p. 73-76.

[15] Zock PL, Katan MB. Hydrogenation alternatives: effects of trans-fatty acids and stearic acid versus linoleic acid on serum lipids and lipoprotein in humans. J. Lipids Res. 1992, 33:p. 399-410.

[16] Smith GF. Mesembs of the World Pretoria.Briza Publications, 2009 , p. 252-255.

[17] Einhorn D, Landsberg L. Nutrition and diet in hypertension: in Shils ME, Young.

[18] eds. Modern Nutrition in Health and Disease ed. 7, Philadelphia. Lea and Febiger, 1988.

[19] Adeboye O. Status of conservation of the indigenous leaf vegetable and fruit of African. African Journal of Biotechnology, 2007, 3: p. 700-705.

[20] Richard AE, Djukwo VN, Gouado I, Mbofung CM. Nutritional Component of Some non-Conventional Leaf Vegetable Consumed in Cameroon. Pakistan Journal of Nutrition, 2007, 6(6): p. 712-717.

[21] Olaofe O. Nutritional Component of Some non- Conventional Leaf Vegetable Consumed in Cameroon Food chemistry2007, 51: p. 68-71.

[22] Ola FL, Oboh G. Anti-nutritional Factors, in Nutritional Quality of Plant Foods. The Journal Techno science, 2000, 4: p. 1-3.

[23] FAO/WHO/UNU. Protein and amino acid requirements in human nutrition, WHO Press 2007, p. 150. 